
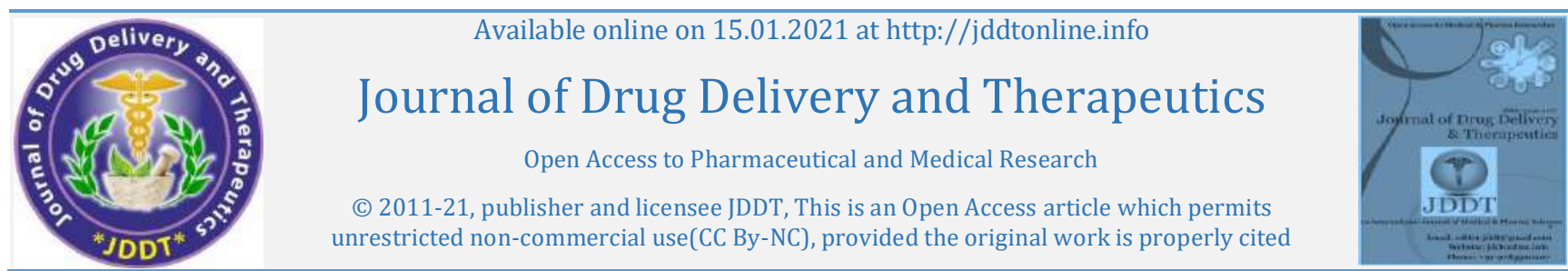

Open

\title{
A review on pharmacokinetics, pharmacodynamics and clinical aspects of remdesivir and favipiravir for the treatment of coronavirus disease
}

\section{Inder Kumar}

School of Pharmacy, Abhilashi University Mandi, HP, India

\author{
Article Info:

\section{Article History:} \\ Received 22 Oct 2020; \\ Review Completed 16 Dec 2020 \\ Accepted 23 Dec 2020; \\ Available online 15 Jan 2021
}

\section{Cite this article as:}

Kumar I, A review on pharmacokinetics,

pharmacodynamics and clinical aspects of remdesivir and favipiravir for the treatment of coronavirus disease, Journal of Drug Delivery and Therapeutics. 2021; 11(1):121-129

DOI: http://dx.doi.org/10.22270/jddt.v11i1.4475

\section{Abstract}

The coronavirus disease has spread all over the world. Till now no medicine, vaccine, and any other monoclonal antibodies have been approved for the diagnosis or prevention of COVID-19. In many countries, doctors are considering "repurposing" different approved drugs like interferon-a, lopinavir/ ritonavir, ribavirin, and chloroquine phosphate, etc. to treat COVID-19. Remedesivir (GS5734) is a prodrug of monophosphoramidate of adenosine analogue. Remedesivir block the viral RNA dependent RNA polymerease (RdRp). Favipiravir (T-705) is also a prodrug and was revealed during evaluating the antiviral activity of chemical agents concerning the influenza virus. This review summarizes the status, mechanisms, preclinical research, and clinical trial progress of remedesivir and favipiravir for the treatment of COVID-19.

Keywords: coronavirus disease, favipiravir, remdesivir, clinical trials, pharmacodynamics

*Address for Correspondence:

Inder Kumar, School of Pharmacy, Abhilashi University Mandi, HP, India

\section{INTRODUCTION}

The world has suffered the most pandemic condition nowadays due to coronavirus disease (COVID-19). In 2019, novel coronavirus originated and now it is rapidly spreading from China (Wuhan City of Hubei Prvince) to the rest of the world. 1, 2 Till now 15 December 2020, there have been 73,353,210 confirmed cases of COVID-19, including 1,631,336 deaths. (https://www.worldometers.info/coronavirus/) India has reported 9,912,054 confirmed cases of COVID-19 with 143,802 deaths and the numbers are still increasing day by day.

(https://www.worldometers.info/coronavirus/country/india/)

The general symptoms of coronavirus include cough, fever, shortness of breath, and dyspnoea. In most cases, SARS-CoV2 infections can lead to death due to kidney and pneumonia, acute respiratory syndrome, and even multiple organ failure. 3, 4 Till now no medicine, vaccine, and any other monoclonal antibodies have been approved for the diagnosis or prevention of COVID-19. In many countries, doctors are considering "repurposing" different approved drugs to treat COVID-19.

Additionally, remedesivir and favipiravir are two drugs now days are approved for treating COVID-19. Remedesivir (GS5734) is a prodrug of monophosphoramidate of adenosine analogue. Remedesivir block the viral RNA dependent RNA polymerease (RdRp). ${ }^{5}$ Favipiravir (T-705) is also a prodrug and was revealed during evaluating the antiviral activity of chemical agents for influenza virus. 6

\section{ORIGIN AND LIFE CYCLE OF SARS-COV-2}

The SARS-CoV-2 strain was first found when a sample is isolated from a worker who's suffering from pneumonia in the Wuhan seafood market. 7 The founded strains of SARSCoV-2 have a length of $29.9 \mathrm{~kb}$. SARS-Cov-2 has four important structural proteins, which include (a) Spike (S) glycoprotein, (b) small envelope (E) glycoproteins, (c) membrane (M) glycoproteins, (d) nucleocapsid (N) protein, and some adjunct proteins. ${ }^{8}$ The $\mathrm{S}$ glycoprotein having a molecular weight of $150 \mathrm{kDa}$ and it is found in the outer portion of the virus. It is a transmembrane protein. Due to the host cell's furin-like protease, the $\mathrm{S}$ glycoprotein is cleaved into their two subunit namely S1 and S2, where S1 is responsible for the identification of the host virus range and cellular tropism and S2 function to mediate virus fusion in the transmitting the host cells. 9-11

The N Protein or also called nucleocapsid is the structural component of $\mathrm{CoV}$ locating in the ER (endoplasmic reticulum)-Golgi region. The $\mathrm{N}$ protein is structurally bound to the nucleic acid material of the virus. The $\mathrm{N}$ protein proposed to lead the structural changes increasing the affinity for viral RNA.9, 12, 13 The main structure of SARS-CoV2 and the life cycle of SARS-CoV-2 is shown in Fig.1 and Fig.2. 


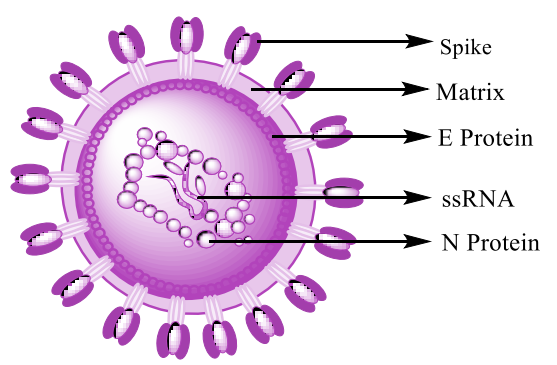

Figure 1: Structure of coronavirus (SARS-CoV-2).

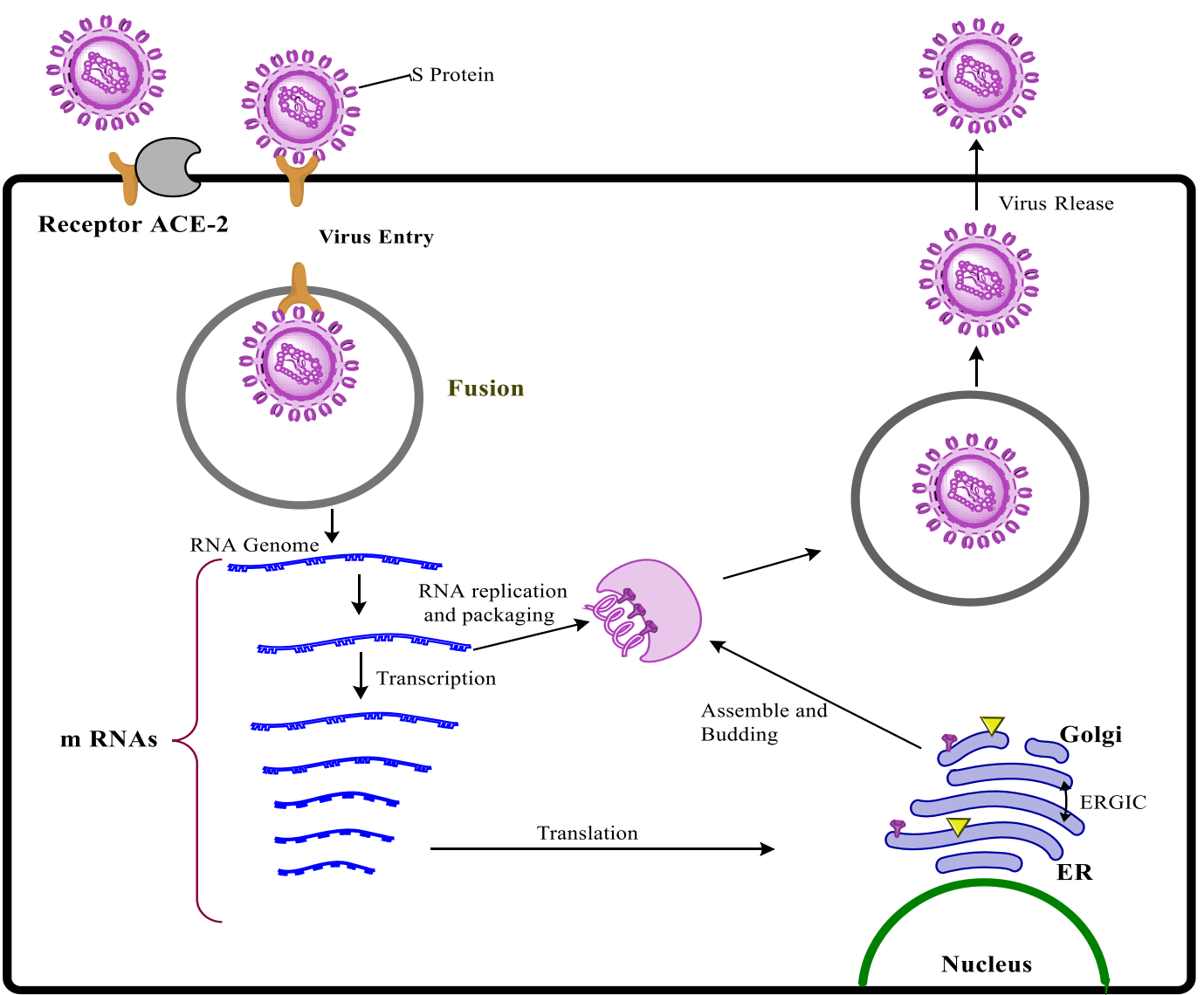

Figure 2: Entry and life cycle of severe acute respiratory syndrome coronavirus. 14-16

\section{PHARMACOLOGY OF REMDESIVIR AND FAVIPIRAVIR}

Remdesivir (GS-5734) is a phosphoramidate prodrug, which inhibits the viral RNA dependent RNA polymerase (RdRp). As RdRp is showing extremely conserved across coronavirus due to its non-structural proteins (nsp12) making it an attractive target for broad-spectrum antiviral drugs. The essential clinical sign of remdesivir is for the treatment of
Ebola virus (EVD) disease but due to the poor efficacy of remdesivir in phase III of clinical trials, it has not been approved for sale for any country. Now remdesivir has been revealed to utilize its activity against the coronavirus Middle East respiratory syndrome-related coronavirus (MERS-CoV) and SARS-CoV). Recently in vitro studies indicated that remdesivir shows an effective action for the treatment and controlling of SARS-CoV-2 infection. 17-20<smiles>CCC(CC)COC(=O)[C@H](C)NP(=O)(OC[C@H]1O[C@@](C#N)(c2ccc3c(N)ncnn23)[C@H](O)[C@@H]1O)Oc1ccccc1</smiles>

(a)<smiles>COP(=O)(O[C@@H]1O[C@@](C#N)(c2ccc3c(N)ncnn23)[C@H](O)[C@@H]1O)OP(=O)(O)OP(=O)(O)O</smiles>

(b)

Figure 3: Chemical structures of (a) remdesivir as the phosphoramidate prodrug of an adenosine C-nucleoside and (b) pharmacologically active nucleoside triphosphate (NTP) as a viral RdRp inhibitor. 
Favipiravir was the first drug used in Wuhan (China) for the treatment of the SARS-Cov-2 virus (coronavirus-COVID-19), when the virus spread all over the world than various countries received the approval of the favipiravir to use a drug as in emergency basis. ${ }^{21,} 22$ In June 2020, it received approval from DCGI in India for mild and moderate COVID-
19 infection. Favipiravir (T-705) is an oral antiviral drug firstly used against the influenza virus and lately, it was used for the treatment of Ebola Virus. Favipiravir (T-1105) a lead compound and its derivatives were found to have antiviral activities. Chemical modification of the pyrazine moiety of T1105 leads to the formation of favipiravir. ${ }^{23,24}$<smiles>NC(=O)c1nc(F)c[nH]c1=O</smiles>

(a)<smiles>NC(=O)c1ncc[nH]c1=O</smiles>

(b)<smiles>NC(=O)c1nccn(C2OC(CO)C(O)C2O)c1=O</smiles>

(c)

Figure 4: Chemical structures of favipiravir (a) T-705 (b) T-1105 (c) T-1106.

\section{PHARMACOKINETICS AND PHARMACODYNAMICS OF REMDESIVIR AND FAVIPIRAVIR}

Remdesivir is a prodrug. Remdesivir is generally administered through IV injection with a dose of $200 \mathrm{mg}$ for adults in one day, followed by the maintenance dose of $100 \mathrm{mg}$ for adults up to 10days. Plasma half-life $\left(T_{1 / 2}\right)$ of remdesivir is $1 \mathrm{hr}$ and their metabolites; alanine metabolite GS-704277 shows plasma half-life $1 \mathrm{hr}$, nucleoside monophosphate metabolite GS- 441524 is $24.5 \mathrm{hrs}$. Remdesivir shows moderate protein binding up to $12.1 \%$. However, metabolites of remdesivir GS-704277 and GS441524 exhibit low plasma protein binding with a mean free fraction of $\geq 85 \%$. Most of the drug is eliminated through urine $(74 \%)$ and the rest of the drug is eliminated through faeces. Remdesivir is a prodrug of a nucleoside analogue, which is used to inhibit the action of RNA polymerase. As it is given once a day, the duration of action is moderate. 25-28

Favipiravir is an orally administered prodrug, having shown greater bioavailability $\sim 94 \%$. It has a low volume of distribution (10e20L) and having a protein binding of 54\%. The maximum concentration of drug reaches to plasma in a single dose with 2 hrs. However, in multiple dosing Tmax and half-life increases. Generally, favipiravir has a short half-life (2.5h) and rapidly eliminated by renal elimination in the hydroxylated form. It exhibits dose-dependent and timedependent pharmacokinetics. As favipiravir is not metabolized by the cytochrome $\mathrm{P} 450$ system but inhibits the CYP2C8 component. Therefore, caution must be needed when co-administered with drugs, which are metabolized by the CYP2C8 systems. ${ }^{6,29-31}$

\section{MECHANISM OF REMDESIVIR AND FAVIPIRAVIR}

Remdesivir is a phosphoramide prodrug of an adenosine $\mathrm{C}$ nucleoside. As it is a prodrug, when a drug is entered into the respiratory epithelial cells in the body, this will be metabolized into its active form i.e. nucleoside triphosphate. 32

The active form of remdesivir can prevent the replication of many coronaviruses in the lung epithelial cells. SARS-CoV-2 is an enclosed, positive-sense, RdRp, which is coded by the virus itself, dominates single-stranded RNA virus. After the virus attacks the host cell, the viral genomic RNA is straight used as a template, and the host cell protein synthesis system is used for the translation of RdRp. 33, 34 RdRp is continuously used to complete the transcriptional synthesis of the negative-strand subgenomic RNA, the synthesis of several structural protein-related mRNAs, and the replication of viral genomic RNA. RdRp can precisely and efficiently synthesize tens of thousands of nucleotides and thus enables all other biological actions after the virus attacks the host cell. Most of the anticoronavirus drugs targeting RdRp are nucleoside analogues. This decreases viral RNA synthesis. ${ }^{28,35,36}$

Studies are continuing to understand whether the prodrug terminates RNA chains or it causes mutations in the RNA. Using Ebola virus studies, it was well known that the prodrug, Remdesivir, inhibited the action of RNA-dependent RNA polymerase, producing the elongation of the synthesized chain. The mechanism of action of remdesivir is shown in Fig. 5. 37 


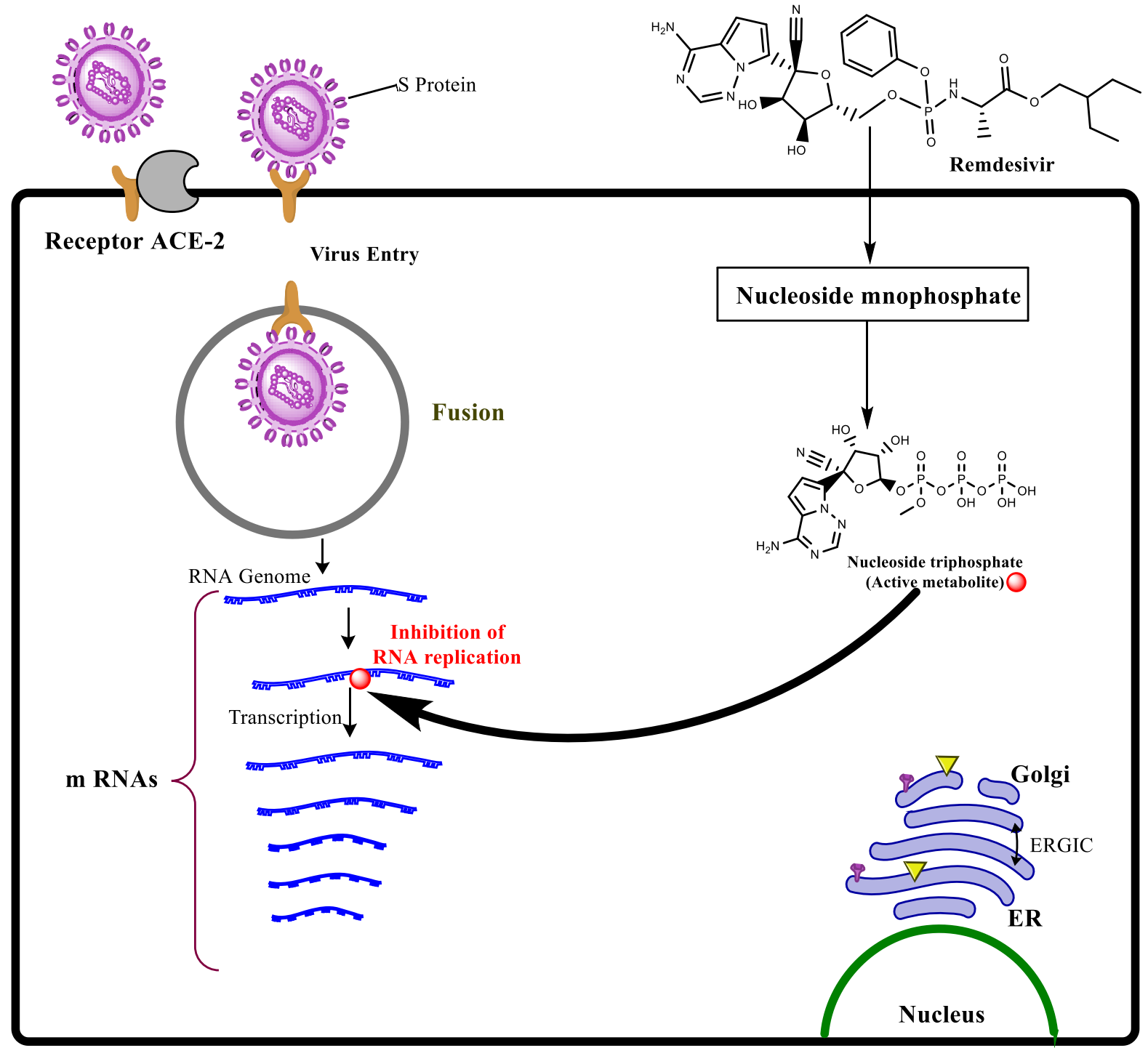

Figure 5: Mechanisms of action of remdesivir.

Favipiravir undergoes phosphor-ribosylation to its active form favipiravir-RTP within the tissue. It shows the antiviral effect through a different mechanism:

(a) The activities for the favipiravir i.e. favipiravir-RTP acts as a substrate for the RNA-dependent RNA-polymerase (RdRp) enzyme. Thus inhibiting its action primary to the elimination of viral protein synthesis. 6 (b) The active form preventing the extension of an RNA strand by combined with the viral RNA strand.

(c) Recently it has been revealed that favipiravir shows lethal mutagenesis in-vitro during influenza virus infection that makes favipiravir a virucidal drug. Whether the same action is revealed against SARS-CoV-2 or not is undefined (Fig. 6). 23, 24, 38, 39 


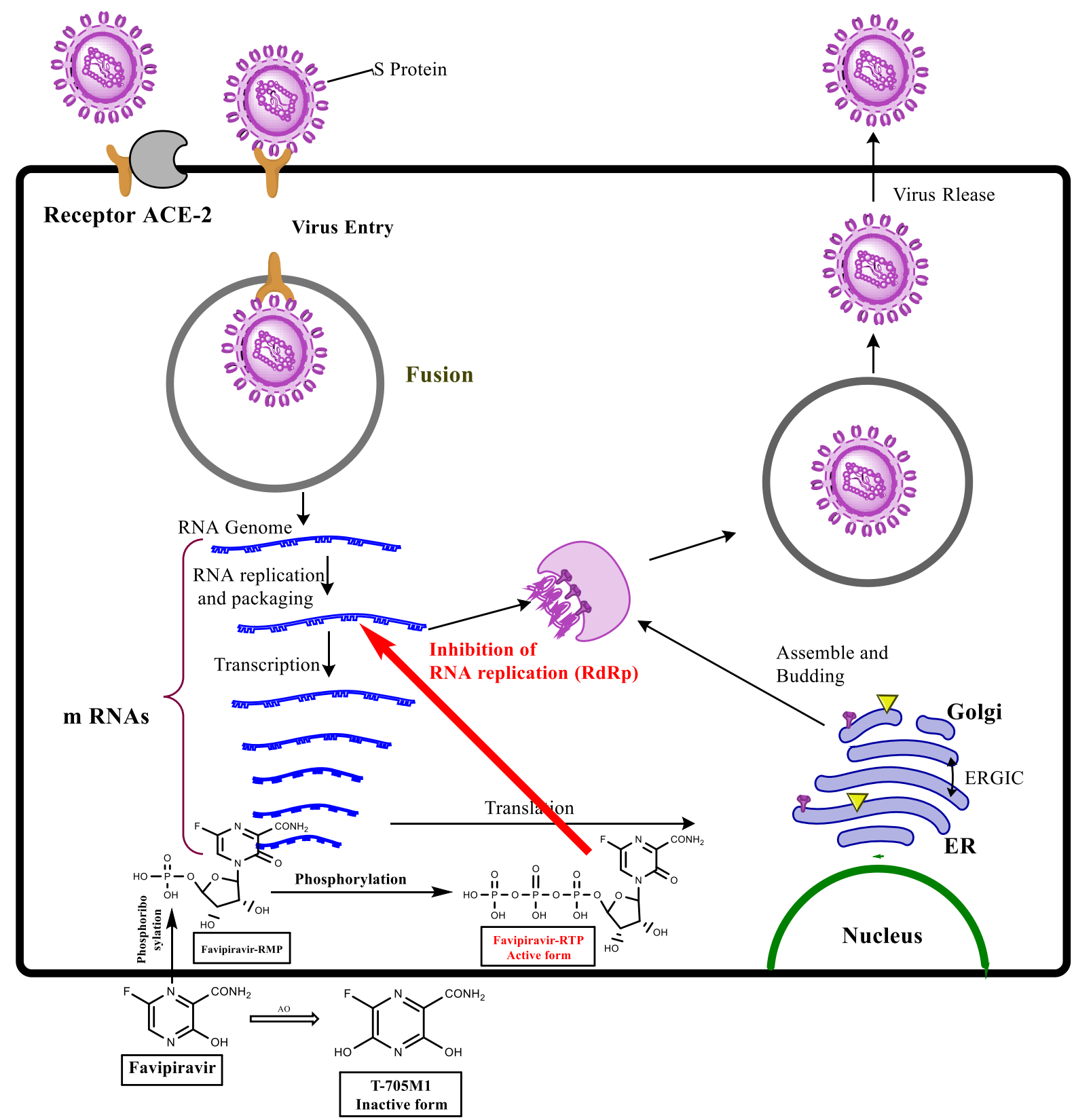

Figure 6: Mechanism of action of favipiravir (T-705) against the virus. Favipiravir is incorporated into cells and converted to favipiravir ibofuranosyl-5'-triphosphate (favipiravir-RTP) by host cells. The triphosphate form, favipiravir-RTP, inhibits the activity of RNA-dependent RNA polymerase (RdRp) of RNA viruses. AO, aldehyde oxidase; RMP, ribosyl monophosphate. 40

\section{CLINICAL ASPECTS OF FAVIPIRAVIR}

Favipiravir (T-705 or Avigan), an oral antiviral medication recognized in Japan for flu contamination in 2014. It has likewise been utilized for the treatment of Ebola infection disease. It acts by direct restraint of viral replication and records through misincorporation in nascent vRNA (viral ribonucleic corrosive), or by binding to preserved polymerase domains, preventing incorporation of nucleotides for vRNA replication and transcription. 6, 41

According to Madelain $\mathrm{V}$ et al 42 nonhuman primate (NHP) model investigation, favipiravir was found to have a versatile safe response in viral clearance and can turn into a treatment choice for other arising viral infections. Different investigations have additionally revealed that favipiravir demonstrations by Inhibiting RNA dependent RNA polymerase (RdRp) by changing over into its dynamic metabolite (favipiravir-ribofuranosyl-50-triphosphate (RTP)) in cells and is perceived as a substrate by viral RNA polymerase. As SARS-CoV-2, is an RNA infection, this medication may be one of the choices for treating COVID-19. 43,44

National Medical Products Administration of China has included this medication for the expected therapies for COVID-19. The clinical evidence on the feasibility of this medication was seen in the clinical trials conducted by the Third People's Hospital of Shenzhen in Guangdong region, where favipiravir group patients' (n $1 / 435)$ lab tests indicated negative for COVID 19 following 4 days of therapy, while other group patients took 11 days for the same.

In an open-label non-randomized control study led by Q Cai et al, favipiravir (FPV) $1600 \mathrm{mg}$ twice day by day as a loading dose and 600mg twice every day in addition to interferon (IFN). In another group lopinavir $400 \mathrm{mg} /$ ritonavir $100 \mathrm{mg}$ (RTV) twice every day in addition to IFN. They noticed a limited viral clearance time and significant improvement in chest imaging in the FPV group with few ADRs. 45

At present, there are 17 clinical trials specific to COVID-19 that are at different periods of improvement and analysts are 
expecting promising outcomes in clearing the virus.35 Recently, a reputed organization has started Phase- 3 clinical trials for COVID-19 in India with tablet favipiravir, and it is expecting the overall investigation results by August (https://www.thehindu.com/news/national/glenmarkbegins-phase-3-clinical-trials-on-antiviral-drug-favipiravirfor-covid-19-patients-in-india/article31563198.ece).

Recently, a stage 3, open name, randomized, multicenter study (CTRI/2020/05/025114, Glenmark Pharmaceuticals) was started in India to decide the adequacy of favipiravir in patients infected with mild to moderate COVID-19 under the worldwide trials progressing for this medication

(http://www.ctri.nic.In/Clinicaltrials/pdf_generate.php?trial id $=43504 \&$ EncHid $=$ \&modid $=$ \&compid $=\%$

$27 \% 2743504 \operatorname{det} \% 27 / 2020$ ). Registered clinical trials of

favipiravir are shown in Table 1.

The investigation enlisted patients with both mild $(\mathrm{N}=90)$ and moderate $(\mathrm{N}=60)$ COVID-19 by separated randomization based on baseline disease severity. The essential target of this investigation was to assess the clinical acceptability and safety of favipiravir combined with standard supportive care. The essential endpoint was time until the end of oral shedding of SARS-CoV-2 infection. The secondary endpoints included - the time from randomization to clinical cure based on clinician assessment, rate of clinical cure at day $4 / 7 / 10 / 14$, rate of SARS-CoV2 RTPCR negativity at day $4 / 7 / 10 / 14$, and time from randomization to hospital discharge. The total length of study support had been a limit of 28 days from the day of randomization. The outcomes from this examination will be significant in the further validation of global evidence on the adequacy and safety treatment against COVID-19.

\section{CLINICAL ASPECTS OF REMDESIVIR}

With the COVID-19 outbreak growing in size and an absence of alternative therapeutics, two clinical trials applying remdesivir were planned and started in China.

On February 5, 2020, a phase 3 randomized, quadrupleblind, placebo-controlled clinical trial was registered at Capital Medical University, to determine the safety and efficacy of remdesivir in patients with mild to moderate SARS-CoV-2 infection (NCT04252664, since suspended).

A day later, a subsequent trial (NCT04257656 since terminated) was enrolled at a similar area focused on patients with progressive COVID-19 respiratory disease. Both trials had planned to trail the primary outcome as a time to clinical enhancement, up to 28 days. Both trials provided remdesivir as a $200 \mathrm{mg}$ loading dose on the first day, with 9 succeeding days of maintenance dosing at 100 $\mathrm{mg}$; this regime is equal to that utilized in the previous NCT03719586 Ebola trial, which performs to be the model for all succeeding trials involving remdesivir (discussed below; Table 2, registered trials of remdesivir). ${ }^{46-48}$

Goldman et al (2020) did randomized, open-label, phase 3 trials including hospitalized patients with COVID-19. Patients were randomly partitioned to get 5 -day and 10-day courses of the intravenous remdesivir. In patients with extreme Covid-19 not requiring mechanical ventilation, there was not any difference between the 5-day and 10-day periods of the intravenous remdesivir. Due to the lack of placebo control, the degree of benefit cannot be determined (ClinicalTrials. gov number: NCT04292899). ${ }^{27}$

Wang et al (2020) led a randomized, double-blind, placebocontrol multicenter trials in adult patients with COVID-19 at ten hospitals in China (ClinicalTrials. gov number: NCT04257656). The 237 patients were randomly separated into the remdesivir (158 cases) and placebo groups (79 cases). Results showed that remdesivir administration is not recognized with a significant change in the time of clinical improvement. However, patients who received remdesivir had a numerically shorter recovery time compared to those who received placebo. 49

A few clinical trials of intravenous remdesivir to treat COVID19 are ongoing. A double-blinded, placebo-controlled trial (ClinicalTrials.gov identifier: NCT04280705) is in progress in the USA in which patients are randomly isolated into two placebo and remdesivir groups. In the remdesivir groups, patients get $200 \mathrm{mg}$ of parenteral remdesivir as an initial dose on the first day, and a maintenance dose of the drug (100 mg once daily) while hospitalized for up to 10 days. The primary outcome of the trial is time to recovery.

A randomized, phase 3 clinical trial of 5 versus 10 days of remdesivir, sponsored by Gilead Sciences, is selecting patients with severe COVID-19 (ClinicalTrials.gov identifier: NCT04292899). Another phase 3, randomized trial of remdesivir (ClinicalTrials.gov identifier: NCT04292730) is the same as NCT04292899 except patients enrolling in that study suffer moderate COVID-19. The main outcome is the number of patients discharged by day 11 .

To access the efficacy and safety of intravenous remdesivir China employing two double-blinded, placebo-controlled trials. 308 targets with mild to moderate COVID-19 hospitalized adults for one trial (ClinicalTrials.gov identifier: NCT04252664) and second trials (ClinicalTrials.gov identifier: NCT04257656) targets 452 hospitalized adults with severe COVID-19. In both trials, the initial dose of remdesivir is $200 \mathrm{mg}$ on day 1 , followed by $100 \mathrm{mg}$ once daily for the remaining days. In both trials, the main outcome measure is the time to clinical recovery. 33

To investigate the safety and efficacy of remdesivir for COVID-19, currently, ten clinical trials are registered (Table 2). 
Table 1: Registered clinical trials of favipiravir for the treatment of COVID-19. 40

\begin{tabular}{|c|c|c|c|}
\hline $\begin{array}{c}\text { Registration } \\
\text { number }\end{array}$ & Design & Intervention & Outcomes \\
\hline ChiCTR2000029544 & $\begin{array}{l}\text { Randomized } \\
\text { controlled } \\
\text { trial }\end{array}$ & $\begin{array}{l}\text { Group A }(n=10) \text { : Antiviral treatment + } \\
\text { BaloxavirMarboxil tablets. } \\
\text { Group B }(n=10) \text { : Antiviral treatment + favipiravir } \\
\text { tablets. } \\
\text { Group C }(n=10) \text { : Antiviral treatment. }\end{array}$ & $\begin{array}{l}\text { Time to viral negativity } \\
\text { by RT-PCR. } \\
\text { Time to clinical } \\
\text { improvement. }\end{array}$ \\
\hline ChiCTR2000029548 & $\begin{array}{l}\text { Randomized, } \\
\text { open-label, } \\
\text { controlled } \\
\text { trial }\end{array}$ & $\begin{array}{l}\text { Group A ( } \boldsymbol{n}=\mathbf{1 0}) \text { : BaloxavirMarboxil: } 80 \mathrm{mg} \text { on } \\
\text { day 1, } 80 \mathrm{mg} \text { on day } 4 ; 80 \mathrm{mg} \text { on day } 7 \text { as } \\
\text { necessary. } \\
\text { Group B }(\boldsymbol{n}=\mathbf{1 0}) \text { : Favipiravir: } 600 \mathrm{mg} \text { ti.d. with } \\
\text { 1,600 mg first loading dosage, no more than } 14 \\
\text { days. } \\
\text { Group C }(\boldsymbol{n}=\mathbf{1 0}) \text { : Lopinavir-Ritonavir: } 200 \mathrm{mg} / 50 \\
\text { mg, twice daily, for } 14 \text { days }\end{array}$ & $\begin{array}{l}\text { Time to viral negativity } \\
\text { by RT-PCR. } \\
\text { Time to clinical } \\
\text { improvement: Time } \\
\text { from start of study drug } \\
\text { to hospital discharge or } \\
\text { to NEWS }<2 \text { for } 24 \\
\text { hours. }\end{array}$ \\
\hline ChiCTR2000029600 & $\begin{array}{l}\text { Randomized } \\
\text { controlled } \\
\text { trial }\end{array}$ & $\begin{array}{l}\text { Group A }(n=30) \text { : Alpha-interferon atomization. } \\
\text { Group B }(n=30) \text { : Lopinavir and Ritonavir + alpha- } \\
\text { interferon atomization. } \\
\text { Group C }(n=30) \text { : Favipiravir + alpha-interferon } \\
\text { atomization. }\end{array}$ & $\begin{array}{l}\text { Declining speed of } \\
\text { SARS-CoV-2 by PCR. } \\
\text { Negative time of SARS- } \\
\text { CoV-2 by PCR. } \\
\text { Incidence rate of chest } \\
\text { imaging. } \\
\text { Incidence rate of liver } \\
\text { enzymes. } \\
\text { Incidence rate of kidney } \\
\text { damage. }\end{array}$ \\
\hline ChiCTR2000029996 & $\begin{array}{l}\text { Randomized } \\
\text { controlled } \\
\text { trial }\end{array}$ & $\begin{array}{l}\text { Group A }(n=20): \text { Favipiravir tablets; } 200 \mathrm{mg} \text {; oral; } \\
\text { twice a day. The adult dose is } 1,600 \mathrm{mg} \text { per time on } \\
\text { first day; treatment: } 10 \text { days. } \\
\text { Group B }(n=20): \text { Favipiravir tablets; } 200 \mathrm{mg} \text {; oral; } \\
\text { twice a day. The adult dose is } 1,800 \mathrm{mg} \text { per time } \\
\text { on the first day; treatment: } 10 \text { days. } \\
\text { Group C }(n=20): \text { Favipiravir tablets; } 200 \mathrm{mg} \text {; } \\
\text { oral; twice a day. The adult dose is } 2,400 \mathrm{mg} \text { per } \\
\text { time on first day; treatment: } 10 \text { days. }\end{array}$ & $\begin{array}{l}\text { Time to clinical } \\
\text { recovery. }\end{array}$ \\
\hline ChiCTR2000030113 & $\begin{array}{l}\text { Randomized } \\
\text { controlled } \\
\text { trial }\end{array}$ & $\begin{array}{l}\text { Group A }(\boldsymbol{n}=\mathbf{1 5}) \text { : Keep ritonavir/ritonavir } \\
\text { treatment. } \\
\text { Group B }(\boldsymbol{n}=\mathbf{1 5}) \text { : Favipiravir }\end{array}$ & $\begin{array}{l}\text { Blood routine tests. } \\
\text { Liver function } \\
\text { examination. } \\
\text { Renal function } \\
\text { examination. } \\
\text { Blood gas analysis. } \\
\text { Chest CT examination. }\end{array}$ \\
\hline ChiCTR2000030254 & $\begin{array}{l}\text { Randomized } \\
\text { controlled } \\
\text { trial }\end{array}$ & $\begin{array}{l}\text { Group A }(n=120): \text { Favipiravir tablets. } \\
\text { Group B }(n=120) \text { : Arbidol tablets. }\end{array}$ & $\begin{array}{l}\text { Clinical recovery rate of } \\
\text { day } 7 .\end{array}$ \\
\hline ChiCTR2000030894 & $\begin{array}{l}\text { Randomized } \\
\text { controlled } \\
\text { trial }\end{array}$ & $\begin{array}{l}\text { Group A }(n=90) \text { : Favipiravir combined with } \\
\text { Tocilizumab. } \\
\text { Group B }(\boldsymbol{n}=\mathbf{3 0}) \text { : Favipiravir. Group C }(n=30) \\
\text { Tocilizumab. }\end{array}$ & Clinical cure rate. \\
\hline ChiCTR2000030987 & $\begin{array}{l}\text { Randomized } \\
\text { controlled } \\
\text { trial }\end{array}$ & $\begin{array}{l}\text { Group A }(\boldsymbol{n}=\mathbf{5 0}) \text { : The oral trial drug favipiravir } \\
\text { tablets plus chloroquine phosphate tablets. } \\
\text { Group B }(\boldsymbol{n}=\mathbf{5 0}) \text { : Oral trial drug favipiravir tablets. } \\
\text { Group C }(\boldsymbol{n}=\mathbf{5 0}) \text { : Oral placebo treatment }\end{array}$ & $\begin{array}{l}\text { Improvement or } \\
\text { recovery of respiratory } \\
\text { symptoms Viral nucleic } \\
\text { acid shedding. }\end{array}$ \\
\hline $\begin{array}{l}\text { JPRN- } \\
\text { jRCTs031190226 }\end{array}$ & $\begin{array}{l}\text { Randomized, } \\
\text { controlled } \\
\text { trial }\end{array}$ & \multicolumn{2}{|c|}{$\begin{array}{l}\text { A prospective multi-centre open trial to assess the safety and efficacy of Favipiravir in } \\
\text { patients infected with covid-19. }\end{array}$} \\
\hline PRN-jRCTs041190120 & $\begin{array}{l}\text { Randomized, } \\
\text { open-label, } \\
\text { controlled } \\
\text { trial }\end{array}$ & \multicolumn{2}{|c|}{$\begin{array}{l}\text { Multicentre, open-label randomised trial of favipiravir in asymptomatic and } \\
\text { minimally symptomatic patients infected with SARS-Cov2 to evaluate viral load } \\
\text { reduction. }\end{array}$} \\
\hline NCT04273763 & $\begin{array}{l}\text { Randomized, } \\
\text { controlled } \\
\text { trial }\end{array}$ & \multicolumn{2}{|c|}{$\begin{array}{l}\text { Evaluating the Efficacy and Safety of Bromhexine Hydrochloride Tablets Combined } \\
\text { With Standard Treatment/ Standard Treatment in Patients With Suspected and Mild } \\
\text { Novel Coronavirus Pneumonia (COVID-19). }\end{array}$} \\
\hline NCT04310228 & $\begin{array}{l}\text { Randomized, } \\
\text { controlled } \\
\text { trial }\end{array}$ & \multicolumn{2}{|c|}{$\begin{array}{l}\text { Favipiravir Combined With Tocilizumab in the Treatment of Corona Virus Disease } \\
2019 .\end{array}$} \\
\hline
\end{tabular}

CT, computed tomography; NEWS, national early warning score; PCR, polymerase chain reaction; RT-PCR, real-time polymerase chain reaction; SARS-CoV-2, severe acute respiratory syndrome coronavirus 2 . 
Table 2: Registered Clinical Trials of Remdesivir for the treatment of COVID-19. 33

\begin{tabular}{|c|c|c|c|c|}
\hline $\begin{array}{l}\text { Registration } \\
\text { Number }\end{array}$ & Official Title & Status & Country & $\begin{array}{l}\text { Estimated Study } \\
\text { Completion Date }\end{array}$ \\
\hline NCT04257656 & $\begin{array}{l}\text { A phase 3, randomized, double-blind, placebo-controlled, } \\
\text { multicenter study to evaluate the efficacy and safety of } \\
\text { remdesivir in hospitalized adult patients with severe } \\
\text { COVID-19 }\end{array}$ & Terminated & China & April 10, 2020 \\
\hline NCT 04365725 & $\begin{array}{l}\text { A multicenter, retrospective study of the effects of } \\
\text { remdesivir in the treatment of severe COVID-19 infections }\end{array}$ & Recruiting & France & June 2020 \\
\hline NCT04302766 & $\begin{array}{l}\text { An intermediate-size patient population expanded access } \\
\text { treatment protocol for coronavirus disease } 2019 \text { (COVID-19) } \\
\text { using remdesivir (RDV; GS-5734 }{ }^{\mathrm{TM}} \text { ) }\end{array}$ & Available & - & - \\
\hline NCT04252664 & $\begin{array}{l}\text { A phase 3, randomized, double-blind, placebo-controlled } \\
\text { multicenter study to evaluate the efficacy and safety of } \\
\text { remdesivir in hospitalized adult patients with mild and } \\
\text { moderate COVID-19 }\end{array}$ & Suspended & China & April 27, 2020 \\
\hline NCT04323761 & $\begin{array}{l}\text { Expanded access treatment protocol: remdesivir (RDV; GS- } \\
\text { 5734) for the treatment of SARS-CoV-2 (CoV) infection }\end{array}$ & Available & - & - \\
\hline NCT04410354 & $\begin{array}{l}\text { A phase 2, randomized, double-blind, placebo-controlled } \\
\text { study of the efficacy and safety of oral merimepodib in } \\
\text { combination with intravenous remdesivir in adult patients } \\
\text { with advanced coronavirus disease } 2019 \text { (COVID-19) }\end{array}$ & Recruiting & USA & August 2020 \\
\hline NCT04292730 & $\begin{array}{l}\text { A phase 3, randomized study to evaluate the safety and } \\
\text { antiviral activity of remdesivir (GS-5734 } \\
\text { with severe COVID-19 }\end{array}$ & $\begin{array}{l}\text { Active, not } \\
\text { recruiting }\end{array}$ & - & June 2020 \\
\hline NCT04409262 & $\begin{array}{l}\text { A phase 3, randomized, double-blind, multicenter study to } \\
\text { evaluate the efficacy and safety of remdesivir plus } \\
\text { tocilizumab compared with remdesivir plus placebo in } \\
\text { hospitalized patients with severe COVID-19 pneumonia }\end{array}$ & Recruiting & - & July 31, 2020 \\
\hline NCT04431453 & $\begin{array}{l}\text { A phase 2/3, single-arm, open-label study to evaluate the } \\
\text { safety, tolerability, pharmacokinetics, and efficacy of } \\
\text { remdesivir (GS-5734 } \\
\text { years of age with COVID-19 }\end{array}$ & $\begin{array}{l}\text { Not yet } \\
\text { recruiting }\end{array}$ & - & December 2020 \\
\hline NCT04330690 & $\begin{array}{l}\text { A multicenter, adaptive, randomized, open-label, controlled } \\
\text { clinical trial of the safety and efficacy of investigational } \\
\text { therapeutics for COVID-19 in hospitalized patients (CATCO: } \\
\text { Canadian Treatments for COVID-19), in conjunction with } \\
\text { the Public Health Emergency SOLIDARITY Trial (World } \\
\text { Health Organization) }\end{array}$ & Recruiting & Canada & May 18,2022 \\
\hline
\end{tabular}

\section{CONCLUSION}

Coronavirus disease is spreading across the world day by day, and still there is no vaccine or any other medicine approved for the treatment of COVID-19. Recently, many researchers recommended the use of favipiravir and remdesivir for the treatment of COVID-19. The review concludes pharmacokinetics, pharmacodynamics and clinical trials related with these drugs for combating against the COVID-19. No drug may be superior or inferior, however, the use of single drug may not be effective enough to control this deadly virus, so use of combination of antivirals with different mechanism of action may be more effective and at the same time, their adverse events should not be underestimated.

CONFLICT OF INTEREST: Declared none.

\section{REFERENCES}

1. Singhal T. A review of coronavirus disease-2019 (COVID-19). The Indian Journal of Pediatrics. 2020:1-6.

2. Zhu N, Zhang D, Wang W, Li X, Yang B, Song J, et al. A novel coronavirus from patients with pneumonia in China, 2019. New England Journal of Medicine. 2020.

3. Jiang F, Deng L, Zhang L, Cai Y, Cheung CW, Xia Z. Review of the clinical characteristics of coronavirus disease 2019 (COVID-19). Journal of general internal medicine. 2020:1-5.

4. Salehi S, Abedi A, Balakrishnan S, Gholamrezanezhad A. Coronavirus disease 2019 (COVID-19): a systematic review of imaging findings in 919 patients. American Journal of Roentgenology. 2020:1-7.

5. Mulangu S, Dodd LE, Davey Jr RT, Tshiani Mbaya O, Proschan M, Mukadi D, et al. A randomized, controlled trial of Ebola virus disease therapeutics. New England Journal of Medicine. 2019; 381(24):2293-303.

6. Furuta Y, Gowen BB, Takahashi K, Shiraki K, Smee DF, Barnard DL. Favipiravir (T-705), a novel viral RNA polymerase inhibitor. Antiviral research. 2013; 100(2):446-54. 
7. Wu F, Zhao S, Yu B, Chen Y-M, Wang W, Song Z-G, et al. A new coronavirus associated with human respiratory disease in China. Nature. 2020; 579(7798):265-9.

8. Jiang S, Hillyer C, Du L. Neutralizing antibodies against SARSCoV-2 and other human coronaviruses. Trends in immunology. 2020.

9. Guo Y-R, Cao Q-D, Hong Z-S, Tan Y-Y, Chen S-D, Jin H-J, et al. The origin, transmission and clinical therapies on coronavirus disease 2019 (COVID-19) outbreak-an update on the status. Military Medical Research. 2020; 7(1):1-10.

10. Fehr AR, Perlman S. Coronaviruses: an overview of their replication and pathogenesis. Coronaviruses: Springer; 2015. p. 1-23.

11. Walls AC, Park Y-J, Tortorici MA, Wall A, McGuire AT, Veesler D. Structure, function, and antigenicity of the SARS-CoV-2 spike glycoprotein. Cell. 2020.

12. Xu H, Zhong L, Deng J, Peng J, Dan H, Zeng X, et al. High expression of ACE2 receptor of 2019-nCoV on the epithelial cells of oral mucosa. International journal of oral science. 2020; 12(1):1-5.

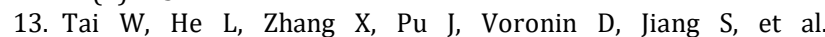
Characterization of the receptor-binding domain (RBD) of 2019 novel coronavirus: implication for development of RBD protein as a viral attachment inhibitor and vaccine. Cellular \& molecular immunology. 2020; 17(6):613-20.

14. Rabi FA, Al Zoubi MS, Kasasbeh GA, Salameh DM, Al-Nasser AD. SARS-CoV-2 and coronavirus disease 2019: what we know so far. Pathogens. 2020; 9(3):231.

15. Simmons G, Zmora P, Gierer S, Heurich A, Pöhlmann S. Proteolytic activation of the SARS-coronavirus spike protein: cutting enzymes at the cutting edge of antiviral research. Antiviral research. 2013; 100(3):605-14.

16. Indwiani Astuti Y. Severe Acute Respiratory Syndrome Coronavirus 2 (SARS-CoV-2): An overview of viral structure and host response. Diabetes \& Metabolic Syndrome. 2020.

17. Beigel JH, Tomashek KM, Dodd LE, Mehta AK, Zingman BS, Kalil AC, et al. Remdesivir for the treatment of Covid-19. New England Journal of Medicine. 2020.

18. Al-Tawfiq JA, Al-Homoud AH, Memish ZA. Remdesivir as possible therapeutic option for the COVID-19. Travel medicine and infectious disease. 2020.

19. McCreary EK, Angus DC. Efficacy of Remdesivir in COVID-19. Jama. 2020; 324(11):1041-2.

20. Norrie JD. Remdesivir for COVID-19: challenges of underpowered studies. The Lancet. 2020; 395(10236):1525-7.

21. Baranovich T, Wong S-S, Armstrong J, Marjuki H, Webby RJ, Webster RG, et al. T-705 (favipiravir) induces lethal mutagenesis in influenza A H1N1 viruses in vitro. Journal of virology. 2013; 87(7):3741-51.

22. Kiso M, Takahashi K, Sakai-Tagawa Y, Shinya K, Sakabe S, Le QM, et al. T-705 (favipiravir) activity against lethal H5N1 influenza A viruses. Proceedings of the National Academy of Sciences. 2010; 107(2):882-7.

23. Seneviratne SL, Abeysuriya V, De Mel S, De Zoysa I, Niloofa R. Favipiravir in COVID-19. International Journal of Progressive Sciences and Technologies. 2020; 19(2):143-5.

24. Agrawal U, Raju R, Udwadia ZF. Favipiravir: A new and emerging antiviral option in COVID-19. Medical Journal Armed Forces India. 2020

25. Tempestilli M, Caputi P, Avataneo V, Notari S, Forini O, Scorzolini L, et al. Pharmacokinetics of remdesivir and GS-441524 in two critically ill patients who recovered from COVID-19. Journal of Antimicrobial Chemotherapy. 2020; 75(10):2977-80

26. Warren TK, Jordan R, Lo MK, Ray AS, Mackman RL, Soloveva V, et al. Therapeutic efficacy of the small molecule GS-5734 against Ebola virus in rhesus monkeys. Nature. 2016; 531(7594):381-5.

27. Godman B. Combating COVID-19: Lessons learnt particularly among developing countries and the implications. Bangladesh Journal of Medical Science. 2020:103-S 8.

28. Grein J, Ohmagari N, Shin D, Diaz G, Asperges E, Castagna A, et al. Compassionate use of remdesivir for patients with severe Covid19. New England Journal of Medicine. 2020; 382(24):2327-36.

29. Mendenhall M, Russell A, Juelich T, Messina EL, Smee DF, Freiberg AN, et al. T-705 (favipiravir) inhibition of arenavirus replication in cell culture. Antimicrobial agents and chemotherapy. 2011; 55(2):782-7.

30. Shiraki K, Daikoku T. Favipiravir, an anti-influenza drug against life-threatening RNA virus infections. Pharmacology \& therapeutics. 2020:107512.

31. Madelain V, Nguyen THT, Olivo A, De Lamballerie X, Guedj J, Taburet A-M, et al. Ebola virus infection: review of the pharmacokinetic and pharmacodynamic properties of drugs considered for testing in human efficacy trials. Clinical pharmacokinetics. 2016; 55(8):907-23.

32. Yang C-J, Wei Y-J, Chang H-L, Chang P-Y, Tsai C-C, Chen Y-H, et al Remdesivir use in the coronavirus disease 2019 pandemic: A mini-review. Journal of Microbiology, Immunology and Infection. 2020.

33. Hashemian SM, Farhadi T, Velayati AA. A review on remdesivir: a possible promising agent for the treatment of COVID-19. Drug design, development and therapy. 2020; 14:3215.

34. Eastman RT, Roth JS, Brimacombe KR, Simeonov A, Shen M, Patnaik S, et al. Remdesivir: A Review of Its Discovery and Development Leading to Emergency Use Authorization for Treatment of COVID-19. ACS Central Science. 2020.

35. Hendaus MA. Remdesivir in the treatment of Coronavirus Disease 2019 (COVID-19): A simplified summary. Journal of Biomolecular Structure and Dynamics. 2020(just-accepted):110.

36. Tchesnokov EP, Gordon CJ, Woolner E, Kocinkova D, Perry JK, Feng JY, et al. Template-dependent inhibition of coronavirus RNA-dependent RNA polymerase by remdesivir reveals a second mechanism of action. Journal of Biological Chemistry. 2020; 295(47):16156-65.

37. Tchesnokov EP, Feng JY, Porter DP, Götte M. Mechanism of inhibition of Ebola virus RNA-dependent RNA polymerase by remdesivir. Viruses. 2019; 11(4):326.

38. Furuta Y, Takahashi K, Shiraki K, Sakamoto K, Smee DF, Barnard DL, et al. T-705 (favipiravir) and related compounds: Novel broad-spectrum inhibitors of RNA viral infections. Antiviral research. 2009; 82(3):95-102.

39. Shannon A, Selisko B, Huchting J, Touret F, Piorkowski G, Fattorini $\mathrm{V}$, et al. Rapid incorporation of Favipiravir by the fast and permissive viral RNA polymerase complex results in SARSCoV-2 lethal mutagenesis. Nature communications. 2020; 11(1):1-9.

40. Du YX, Chen XP. Favipiravir: pharmacokinetics and concerns about clinical trials for 2019-nCoV infection. Clinical Pharmacology \& Therapeutics. 2020.

41. da Silva MAG. Favipiravir and Coronavirus. future.1:6

42. Madelain V, Mentré F, Baize S, Anglaret X, Laouénan C, Oestereich L, et al. Modeling favipiravir antiviral efficacy against emerging viruses: from animal studies to clinical trials. CPT: Pharmacometrics \& Systems Pharmacology. 2020.

43. Dong $\mathrm{L}, \mathrm{Hu} \mathrm{S}$, Gao J. Discovering drugs to treat coronavirus disease 2019 (COVID-19). Drug discoveries \& therapeutics. 2020;14(1):58-60.

44. Delang L, Abdelnabi R, Neyts J. Favipiravir as a potential countermeasure against neglected and emerging RNA viruses. Antiviral research. 2018; 153:85-94.

45. Cai Q, Yang M, Liu D, Chen J, Shu D, Xia J, et al. Experimental treatment with favipiravir for COVID-19: an open-label control study. Engineering. 2020.

46. Yang X, Liu Y, Liu Y, Yang Q, Wu X, Huang X, et al. Medication therapy strategies for the coronavirus disease 2019 (COVID-19): recent progress and challenges. Expert Review of Clinical Pharmacology. 2020; 13(9):957-75.

47. Wang Y, Zhou F, Zhang D, Zhao J, Du R, Hu Y, et al. Evaluation of the efficacy and safety of intravenous remdesivir in adult patients with severe COVID-19: study protocol for a phase 3 randomized, double-blind, placebo-controlled, multicentre trial. Trials. 2020; 21(1):422.

48. Wang Y, Zhang D, Du G, Du R, Zhao J, Jin Y, et al. Remdesivir in adults with severe COVID-19: a randomised, double-blind, placebo-controlled, multicentre trial. Lancet (London, England) 2020; 395(10236):1569-78.

49. Wang Y, Zhang D, Du G, Du R, Zhao J, Jin Y, et al. Remdesivir in adults with severe COVID-19: a randomised, double-blind placebo-controlled, multicentre trial. The Lancet. 2020. 